DOI: $10.6060 / \mathrm{mhc} 190659 \mathrm{k}$

\title{
Comparison of Photodynamic Activities of Molecular Oxygen and Porphyrins
}

\author{
A. A. Krasnovsky, ${ }^{\circledR}$ A. S. Kozlov, A. S. Benditkis \\ Federal Research Center of Biotechnology of the Russian Academy of Sciences, 119071 Moscow, Russia \\ ${ }^{\circledR}$ Corresponding authorE-mail: phoal@mail.ru
}

\begin{abstract}
An idea that low level laser therapy (LLLT) by visible and infrared light results from direct excitation of oxygen molecules by laser radiation attracts keen attention of medical community as an alternative for classic photodynamic therapy (PDT) with porphyrin photosensitizers. Present paper deals with testing this idea based on experimental analysis of the rates of singlet oxygen generation upon direct and porphyrin-photosensitized excitation of $\mathrm{O}_{2}$ dissolved in aerated organic solvents and water under normal conditions. In aerated solvents having no porphyrins, singlet oxygen generation was observed under laser excitation at the wavelengths corresponding to the triplet-singlet transitions in monomeric oxygen molecules. The strongest effect was observed under excitation at 1273 and $765 \mathrm{~nm}$, weaker activity was detected under excitation at 1070 and $690 \mathrm{~nm}$. Under excitation at $630 \mathrm{~nm}\left(\leq 300 \mathrm{~mW} / \mathrm{cm}^{2}\right)$ corresponding to the absorption band of oxygen dimols, no reliable singlet oxygen generation was found. Kinetic analysis of the rates of singlet oxygen generation allowed estimation of absorbance and molar absorption coefficients corresponding to the absorption maxima of dissolved oxygen molecules. The obtained results were compared with the absorption coefficients of metal-free protoporphyrin IX. Analysis indicates that under the action of red light on porphyrins, which are always present in normal cells at a concentration of 10-50 nM, singlet oxygen should be produced with the efficiency, which is at least by two orders higher than that under the action of red light on dissolved oxygen in the porphyrin lacking systems. The increase in the concentration of porphyrins that occurs as a result of inflammation, porphyrias or application in PDT, leads to an increase of the efficiency of photodynamic action by another 2-4 orders of magnitude. Hence, photosensitization by porphyrins should contribute incomparably more than photosensitization by oxygen to biological action of red and visible light incomparably more than photosensitization by oxygen. Lacking the IR absorption bands in the absorption spectra of porphyrins excludes the involvement of porphyrins in photosensitization of biomedical processes caused by IR light. In this case oxygen molecules may serve as IR photosensitizers. However, the efficiency of the photosensitization by oxygen was shown to be very low, therefore a real contribution of this process to biomedical action of IR light cannot be considered to be fully established, so, further studies are needed.
\end{abstract}

Key words: Molecular oxygen, singlet oxygen, porphyrins, direct oxygen excitation.

\section{Сравнительный анализ фотодинамической активности растворенного кислорода и порфиринов}

\author{
А. А. Красновский, ${ }^{@}$ А. С. Козлов, А. С. Бендиткис \\ ФИЦ Биотехнологии РАН, 119071 Москва, Россия \\ ${ }^{\circledR}$ E-mail: phoal@mail.ru
}

\begin{abstract}
В настоящее время активно обсуждается представление о том, что лазерная стимуляция клеток и лазерная терапия могут быть результатом прямого возбуждения молекул кислорода лазерным излучением и поэтому служат альтернативой классической фотодинамической терапии (ФДТ) с порфириновыми фотосенсибилизаторами. Настоящая работа посвящена анализу этой гипотезы на основе экспериментального сравнения скоростей генеращии синглетного кислорода при фотосенсибилизированном порфиринами и прямом лазерном возбуждении $\mathrm{O}_{2}$ в органических растворителях и воде при нормальных условиях. Установлено, что в насыщенных воздухом растворителях, не содержащих порфирины, генерация синглетного кислорода возникает при лазерном возбуждении в области длин волн, соответствующих триплет-синглетным
\end{abstract}


переходам в мономерных молекулах кислорода. Наибольший эффект наблюдали при возбуждении при 1273 и 765 нм, более слабый - при возбуждении в области 1070 и 690 нм. При возбуждении в области 630 нм ( $\leq 300$ мBm/ $\left.\mathrm{cm}^{2}\right)$, соответствующей поглощчению димолей кислорода, генерацию синглетного кислорода достоверно обнаружить не удавалось. Кинетический анализ скоростей образования синглетного кислорода позволил измерить оптическую плотность и молярные коэффициенты поглощчения в главных максимумах поглощения кислородных молекул. Полученные значения сопоставлены с абсорбционными коэффициентами безметального протопорфирина IX. Анализ показывает, что при действии красного света порфирины, которые всегда присутствуют в нормальных клетках в концентрации 10-50 нМ, должны генерировать синглетный кислород сэффективностью, которая по крайнеймерена двапорядкабольше, чемпридействиикрасногосветанакислород в не содержащих порфирины системах. Увеличение кониентрации порфиринов в тканях, происходящее при воспалении, порфириях или при применении в ФДТ, должно приводить к усилению фотодинамического действия ещзе на 2-4 порядка величины. Отсюда следует, что при биологическом и терапевтическом действии красного и видимого света процесс фотосенсибилизации порфиринами существенно более вероятен, чем фотосенсибилизачия кислородом. Отсутствие у порфиринов ИК полос поглощения полностью исключает их участие в биомедицинских эффектах, вызванных ИК светом. Фоторецепторами в этом случае могут служить молекуль кислорода. Однако из-за крайне низкой квантовой эффективности фотосенсибилизации кислородом в естественных условиях вопрос о реальном вкладе этого механизма в настоящее время нельзя считать полностью решенным, необходимы дальнейшие исследования.

Ключевые слова: Молекулярный кислород, синглетный кислород, порфирины, прямое возбуждение кислорода.

\section{Introduction}

It is known that oxygen molecules have triplet ground state and two relatively low-lying singlet levels. Figure 1 shows energy diagram for the major electronic transitions in monomeric oxygen molecules in rarified gas as follows from measurements of the absorption spectra of oxygen in Earth atmosphere and in gaseous oxygen at atmospheric pressure. These transitions are highly forbidden therefore the absorption bands of monomeric oxygen molecules are very weak. $\cdot^{[1-5]}$

Stronger bands were obtained in the gas phase and solutions at oxygen pressure 50-140 atm. However, under high pressure the absorption spectra corresponded predominantly to dimols $\left(\mathrm{O}_{2}\right)_{2}$. In the dimol spectra, the IR maxima analogous to those of monomols are shifted by $2-3 \mathrm{~nm}$ toward shorter wavelengths (1263, 1063, 760 and $690 \mathrm{~nm})$, and a series of additional maxima corresponding to simultaneous transitions in two oxygen molecules appear in the visible region (630, $577 \mathrm{~nm}$ and others). Relative intensities of the IR absorption peaks of dimols are strongly different from those of monomols at atmospheric pressure. For instance, the absorption coefficients corresponding to IR bands of dimols (at 1270 and $1070 \mathrm{~nm}$ ) are about 1000 times greater than those for oxygen monomers in the gas phase $\mathrm{e}^{[6-11]}$ (compare Figures 1 and 2).
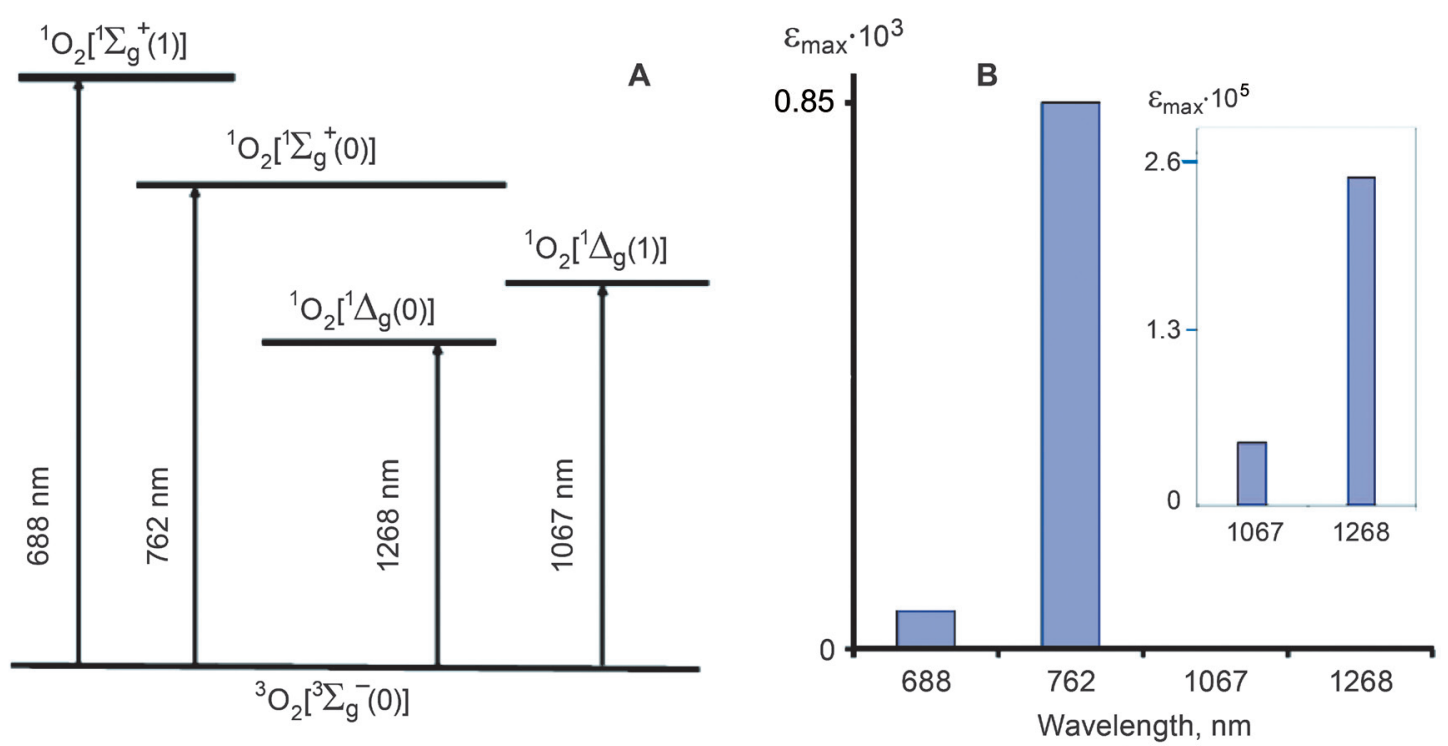

Figure 1. Main electronic transitions in monomeric oxygen molecules in rarified gas. A: Energy diagram. Wavelengths correspond to the absorption maxima. The vibrational sublevels are shown in round brackets. B: Relative intensities of the oxygen bands, $\varepsilon_{\max }$, denote the molar absorption coefficients of gaseous oxygen at 1 bar pressure. Inset shows relative intensities of the bands at 1268 and $1067 \mathrm{~nm} \cdot{ }^{[1-5]}$ 
Direct spectrophotometric measurements of the absorption spectra of dissolved oxygen under normal conditions have not been done so far because these bands are very weak and hidden under optical effects of solvents. The only exclusion is recent measurement of the absorption band at $765 \mathrm{~nm}$, in iodobenzene, which strongly (in 20 times) enhances this transition due to the heavy atom effect. $^{[12]}$

It was reported in classic papers by Evans ${ }^{[7]}$ and Matheson's group ${ }^{[13,14]}$ that excitation of oxygen dimols dissolved in organic solvents at oxygen pressure of 130-140 atm leads to formation of the ${ }^{1} \Delta_{\mathrm{g}}$ singlet oxygen, which causes oxygenation of added organic singlet oxygen traps, aminoacids, proteins and other molecules. Based on these experiments, Ambartzumian and his collaborators advanced an idea that direct laser excitation of intrinsic dimol and monomol oxygen molecules in living cells might be a reason for biological action of laser radiation in visible and infrared region. ${ }^{[15,16]}$ It was also suggested that laser excitation of oxygen might be applied to destruction of cancer cells in vitro and in animal and human organisms. Therefore, photodynamic action of oxygen molecules (light-oxygen effect) might be an alternative for classic PDT. ${ }^{[16,17]}$

These papers attracted keen attention of medical community especially as biological and therapeutic action of red and IR lasers had already been well known (see ${ }^{[18,19]}$ and refs. therein). For more recent and more detailed information on this subject one can refer to the reviews. ${ }^{[20-22]}$ However, to prove this idea reliable experimental information on the absorption spectrum of dissolved oxygen under normal conditions was needed.

More than decade ago, our group started work on mimicking biological effects of laser radiation in solutions of singlet $\left({ }^{1} \Delta_{\mathrm{g}}\right)$ oxygen traps in organic solvents and water at normal pressure and temperature. It was established that monomeric oxygen molecules dissolved in these solvents work as photosensitizers of oxygenation reactions. Kinetic analyses of the reaction rates allowed us to develop methods for calculation of absorbance (optical density) for the maxima of the oxygen absorption bands under natural conditions. ${ }^{[23-32]}$ Later, major results of our studies were confirmed by other researchers. ${ }^{[12,33,34]}$ Recently, these data were complemented by measurement

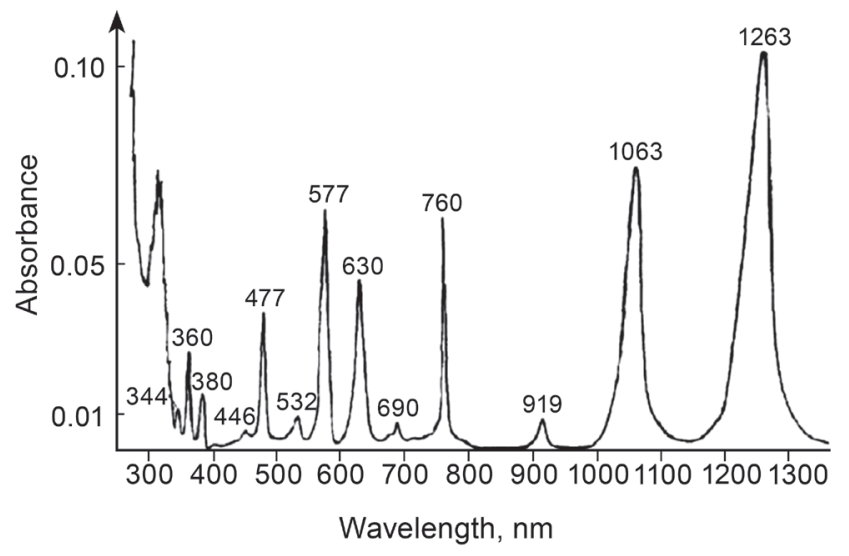

Figure 2. Absorption spectrum of oxygen dimols in compressed oxygen at $150 \mathrm{~atm}$ in the $5 \mathrm{~cm}$ optical path. ${ }^{[1]}$ of IR phosphorescence at $\sim 1270 \mathrm{~nm}$ upon direct excitation of oxygen by red and dark red light. ${ }^{[12,32,35,36]}$ Present paper shortly summarizes the results obtained by our group during investigation of the absorption properties of dissolved oxygen and relative photodynamic activities of oxygen and porphyrins.

\section{Experimental}

Principles of the experiments on oxygenation of chemical traps under direct excitation of dissolved oxygen are illustrated by Figure 3 .

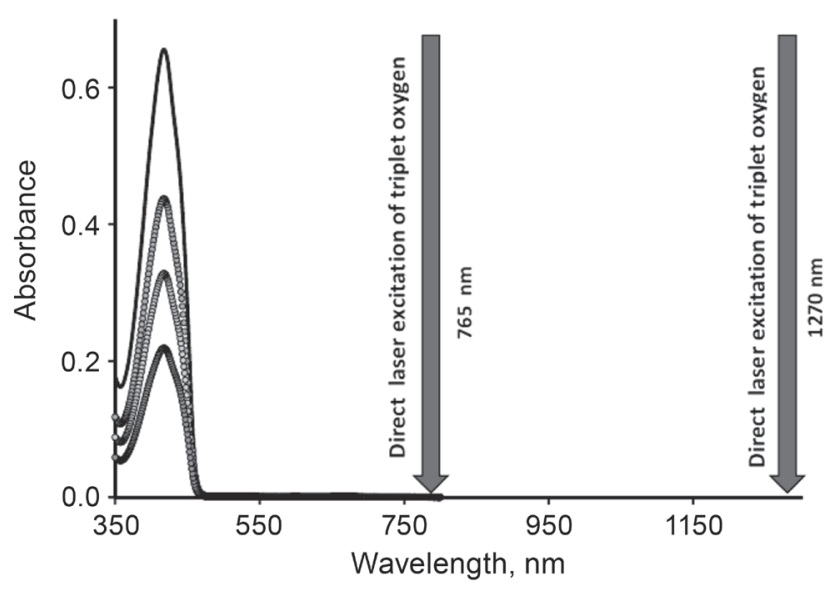

Figure 3. Absorption spectra of the singlet oxygen trap 1,3-diphenylisobenzofuran (the maximum is at $414 \mathrm{~nm}$ ). The trap is bleached under laser irradiation at 765 or $1273 \mathrm{~nm}$ corresponding to the absorption maxima of dissolved oxygen. Absorbance of oxygen at 765 and $1273 \mathrm{~nm}$ is $\leq 10^{-5}$ [30-32] therefore, on the scale of this figure, these maxima are not seen.

For irradiation of samples diode lasers ("LAMI Gelios, Surgical innovative technologies", Moscow, and "Milon-Lachta", St. Petersburg), LEDs ("Polironik", Moscow, and "Alkom Medika" St. Petersburg), gold vapor laser "Auran", tunable forsterite and titanium-sapphire lasers (Institute of Physics RAS, Troitzk) and xenon lamp $(450 \mathrm{~W})$ with a monochromator from Perkin Elmer MPF-44B were used. The eliciting light power was controlled by the power meters Ophir ORION-TH with 20C-SH sensor head (Israel) and ThorLabs PM-100D with S120VC sensor head (USA). Solutions were irradiated in the $10 \mathrm{~mm}$ rectangular quartz cells under normal pressure and room temperature. Volume of the solutions was $1.5 \mathrm{ml}$. Diameter of the irradiated spot was $5-8 \mathrm{~mm}$.

Tetracene (Aldrich Chemistry), 1,3-diphenylisobenzofuran (DPIBF), rubrene and uric acid (Acros Organics) were used as singlet oxygen traps. Tetraphenylporphyrin (TPP) and protoporphyrin IX (Aldrich Chemistry) were employed as photosensitizers of singlet oxygen production. Absorption spectra were measured using a Hitachi U-3400 (Japan) and SF-56 ("LOMO Spektr", St. Petersburg) spectrophotometers. The rate of ${ }^{1} \mathrm{O}_{2}$ formation was calculated from the rate of photobleaching of the main absorption maxima of the traps (474 $\mathrm{nm}$ for tetracene, $410-414 \mathrm{~nm}$ for DPIBF, $530 \mathrm{~nm}$ for rubrene and $290 \mathrm{~nm}$ for uric acid) under irradiation by IR lasers (see refs. ${ }^{[29-32]}$ for details).

Phosphorescence of singlet oxygen at $1270 \mathrm{~nm}$ was detected using a home-made set-up, based on cooled PMT FEU-112 ("Ekran Optical systems", Novosibirsk). For time-resolved measurements a photon-counting electronic system was used. Excitation was produced by pulsed LEDs and lasers. ${ }^{[32,35,36]}$ 


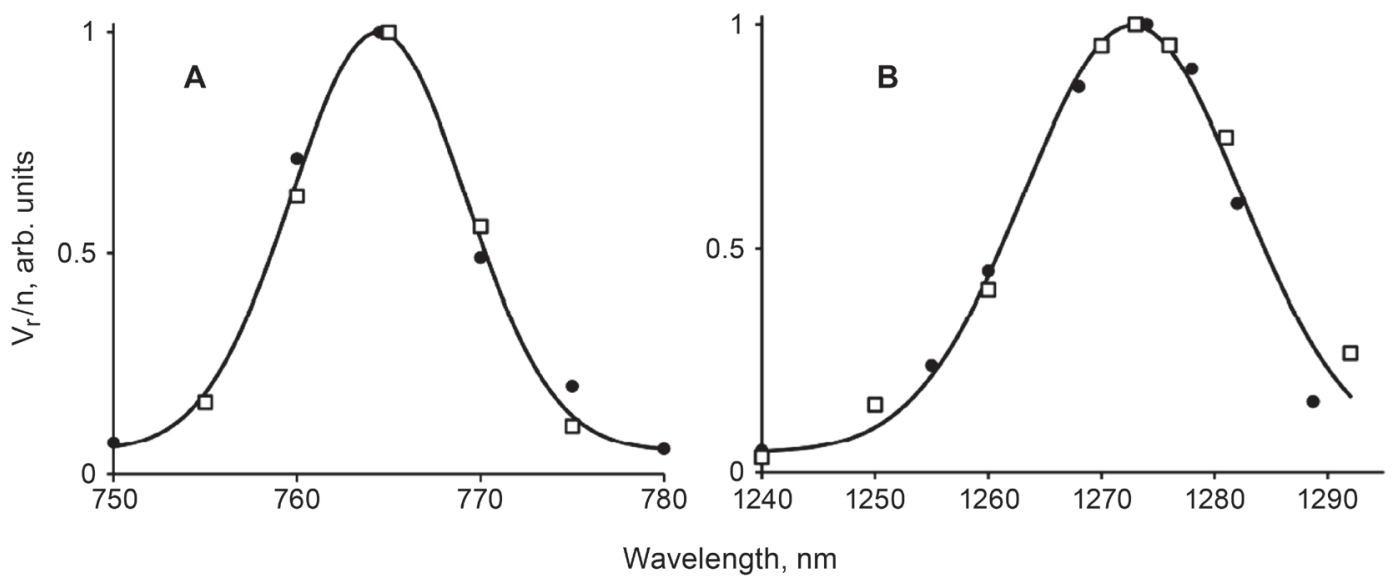

Figure 4. Action spectra of singlet oxygen trapping under direct excitation of oxygen molecules by laser radiation in the spectral region of main oxygen absorption bands. A: spectra obtained using tunable titan-sapphire laser in solutions of tetracene $(\bullet)^{[24]}$ and 1,3-diphenylisobenzofuran $(\square)$ in $\mathrm{CCl}_{4}{ }^{[29]} \mathbf{B}$ : spectra obtained using tunable forsterite laser in solutions of tetracene in $\mathrm{CCl}_{4}(\bullet)^{[23,24]}$ and 1,3-diphenylisobenzofuran in ethanol $(\square) \cdot{ }^{[26]} V_{r}$ is the rate of trap photooxygenation, $n$ is irradiation intensity in number of photons per second.

\section{Results and Discussion}

\section{Direct Excitation of Dissolved Oxygen}

The action spectra for photooxygenation of traps (dependence of the quantum efficiency of oxygenation on laser wavelengths) measured by our group using tunable forsterite and titanium-sapphire lasers in air-saturated $\mathrm{CCl}_{4}$, $\mathrm{C}_{6} \mathrm{~F}_{6}$ and ethanol revealed two major peaks corresponding to the absorption bands of oxygen. The main IR peak was found at $1273 \mathrm{~nm}, 5 \mathrm{~nm}$ longer than in rarefied gas. The width (FWHM) of this band was estimated to be $17-18 \mathrm{~nm}$ $\left(106 \mathrm{~cm}^{-1}\right)^{[24,27-30]}$ (Figure 4). More recently these results were confirmed by Courtade's group in France who observed the oxygen excitation band at $1273 \mathrm{~nm}$ in $\mathrm{CCl}_{4}$, acetone, ethanol and $\mathrm{D}_{2} \mathrm{O}$ with FWHM $\sim 15 \mathrm{~nm} \cdot{ }^{[33,34]}$

The second band was found at $765 \mathrm{~nm}$, at $2 \mathrm{~nm}$ longer wavelengths than in rarefied gas. The band width was estimated to be $8-9 \mathrm{~nm}\left(\sim 130 \mathrm{~cm}^{-1}\right)$ in $\mathrm{CCl}_{4}$ and hexafluorobenzene. ${ }^{[27,29]}$ Recently Ogilby's group in Denmark supported this observation using detection of IR phosphorescence at $\sim 1270 \mathrm{~nm}$ upon direct laser excitation of dissolved oxygen by dark red light. In the phosphorescence excitation spectra in $\mathrm{CCl}_{4}$, the maximum was observed at $765 \mathrm{~nm}$ with the band width of about $7 \mathrm{~nm}\left(120 \mathrm{~cm}^{-1}\right)$. In other solvents, the excitation maxima varied within $763-772 \mathrm{~nm}$ and FWHM - within $6-17 \mathrm{~nm}^{[12]}$

The oxygenation of chemical traps was also observed upon laser irradiation of solvents at 1070, 690 and $630 \mathrm{~nm} \cdot{ }^{[35,36]}$ Detailed information will be presented in the forthcoming paper of our group. As mentioned earlier (Figures 1 and 3), these wavelengths correspond to the vibrational transitions (1070 and $690 \mathrm{~nm})$ and oxygen dimols $(630 \mathrm{~nm})$. The latter wavelength also coincides with the vibrational transition $\left({ }^{3} \Sigma_{\mathrm{g}}^{-} \leftarrow{ }^{1} \Delta_{\mathrm{g}}(v=2)\right)$, which is not shown in Figures 1 and 3 , because it is much weaker than others. It was found that in one solvent, relative quantum efficiencies $(V / n)$ of chemical trapping under irradiation at 1273,765 and $1070 \mathrm{~nm}$ did not depend on nature of the traps, ${ }^{[29,31]}$ whereas under irradiation at 690 and $630 \mathrm{~nm}$ strong dependence of $V_{r} / n$ on traps was observed (Figure 5) (detailed publication is in preparation). These facts suggest that the photooxygenation of the traps under IR light $(765-1273 \mathrm{~nm})$ is due to direct excitation of oxygen molecules, whereas the photoactivity under red light $(628$ and $690 \mathrm{~nm}$ ) corresponds, at least partially, to traps or complexes between triplet oxygen and trap molecules.

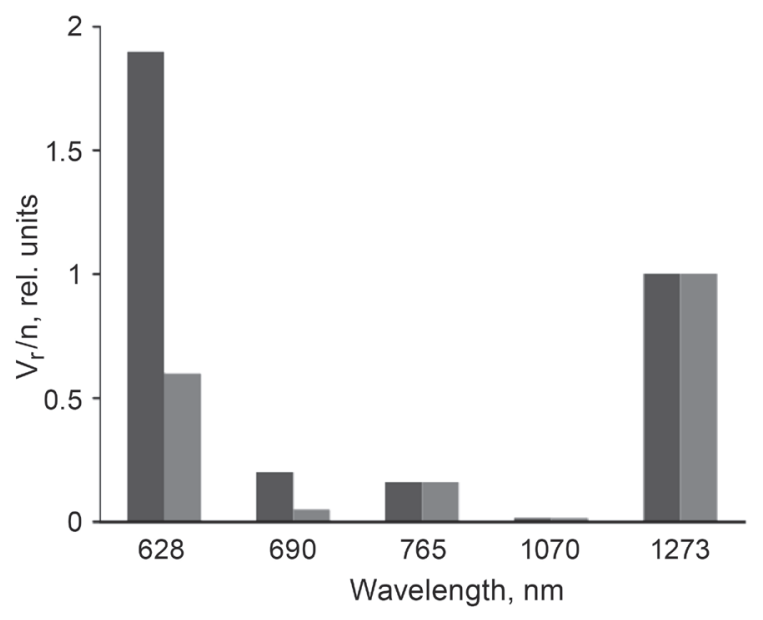

Figure 5. Estimation of the relative quantum efficiencies of singlet oxygen trapping under irradiation at the maxima of the absorption spectra of oxygen dimols and monomols in $\mathrm{CCl}_{4}$. Dark columns - solutions of DPIBF $(40 \mu \mathrm{M})$, grey columns - solutions of tetracene $(150 \mu \mathrm{M})$.

In organic solvents, the oxygenation of the traps under IR light (765 and $1273 \mathrm{~nm}$ ) was shown to be suppressed by a singlet oxygen quencher $-\beta$-carotene. In water and alcohols chemical trapping was inhibited by sodium azide. ${ }^{[23-25]}$ The photoreaction was not detected at all after purging with argon or nitrogen and increased about 5 -fold after purg- 
ing with pure oxygen. ${ }^{[23]}$ More recent results of our group are illustrated by Figure 6. Under both 765 and $1273 \mathrm{~nm}$ light, saturation with pure oxygen caused the (4.8 \pm 0.2$)$-fold increase of the photoreaction rates compared to air-saturated solutions (Figure 6).

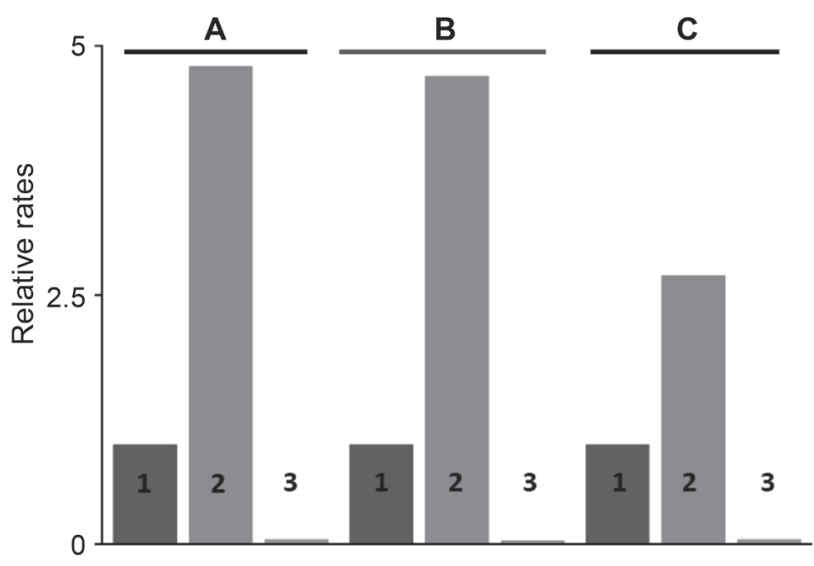

Figure 6. Influence of oxygen concentrations on the rates of singlet oxygen production upon direct excitation of oxygen in $\mathrm{CCl}_{4}$. A, B: measurement of oxygenation rates of DPIBF $(40 \mu \mathrm{M})$ under excitation at $1273 \mathrm{~nm}(\mathrm{~A})$ and $765 \mathrm{~nm}(\mathrm{~B})$. C: the intensities of IR $(1274 \mathrm{~nm})$ phosphorescence of oxygen in $\mathrm{CCl}_{4}$ having no traps under excitation at $765 \mathrm{~nm}$. Numbers indicate solutions saturated with air (1), pure oxygen (2) and argon (3).

Figure 7 illustrates our measurements of phosphorescence arising upon excitation of dissolved oxygen by dark red light in $\mathrm{CCl}_{4}$. It was found that phosphorescence at $\sim 1270 \mathrm{~nm}$ arose under excitation at 765 and $690 \mathrm{~nm}$ and did not appear under excitation by lasers 740 and $810 \mathrm{~nm}$ $\left(\leq 400 \mathrm{~mW} / \mathrm{cm}^{2}\right)$. Addition of $50 \%$ acetone caused the decrease of the oxygen phosphorescence intensity by more than two orders of magnitude. ${ }^{[32,35,36]}$
It is of interest that in $\mathrm{CCl}_{4}$ phosphorescence of oxygen excited at $765 \mathrm{~nm}$ increased by only 2.7 -fold after oxygen purging (Figure 6). This fact is due to the long lifetime of ${ }^{1} \mathrm{O}_{2}$ in this solvent (tens of milliseconds), therefore the saturation of oxygen causes the 1.7-fold quenching of ${ }^{1} \mathrm{O}_{2}$ by triplet oxygen (see ${ }^{[36,37]}$ for details). In the presence of DPIBF, the lifetime of singlet oxygen is strongly reduced, therefore relatively weak quenching effect of oxygen does not influence the rate of ${ }^{1} \mathrm{O}_{2}$ trapping.

Estimation of the phosphorescence excitation spectra, which was made using four diode lasers with fixed emission wavelengths and gold vapor laser $(628 \mathrm{~nm})$, indicated that the most effective wavelengths correspond to the main maxima of the absorption spectra of monomeric oxygen (Figure 8). At the wavelength matching the absorption maximum of oxygen dimols $(628 \mathrm{~nm})$ no reliable signal

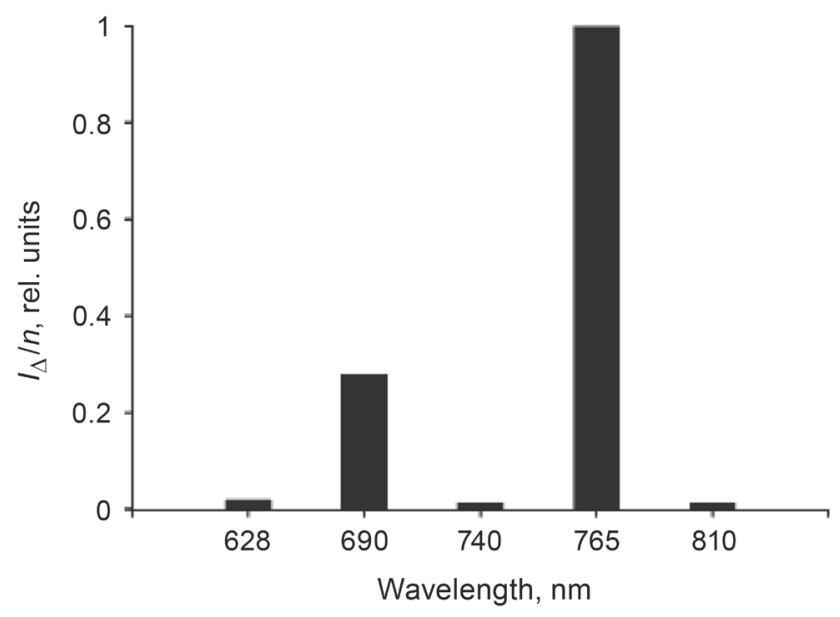

Figure 8. Excitation spectrum of phosphorescence at $1274 \mathrm{~nm}$ in aerated pigment-free $\mathrm{CCl}_{4}$ estimated using five lasers with fixed emission wavelengths. $I_{\Delta}$ is the phosphorescence intensity, $n$ is number of photons of exciting light. a

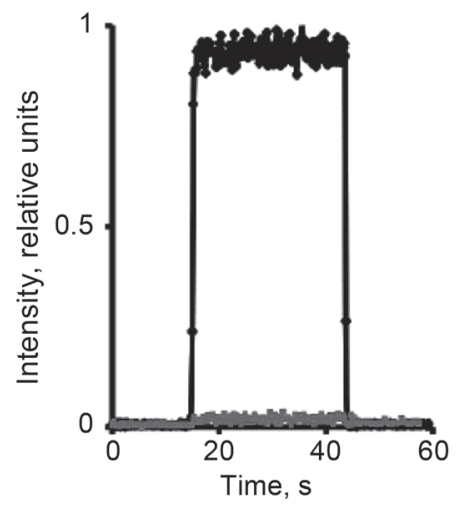

b

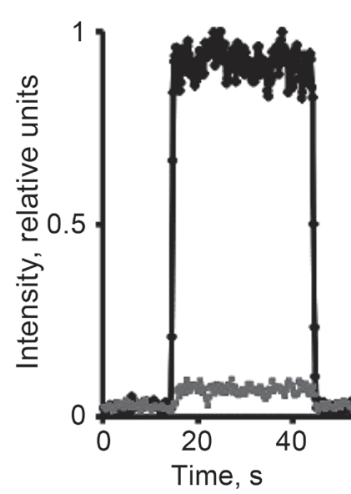

C

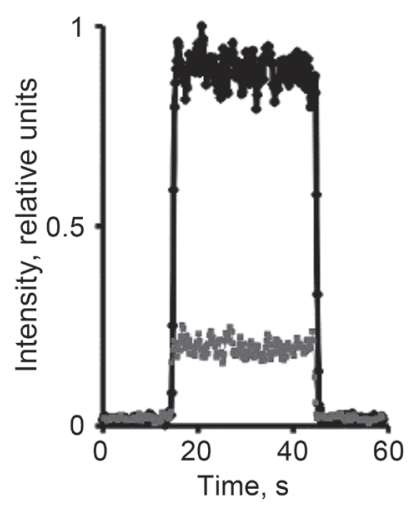

d

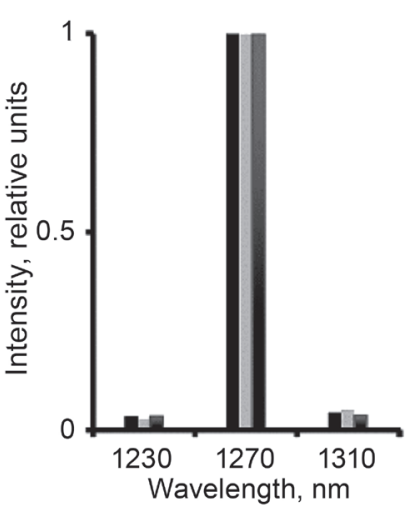

Figure 7. Intensity and spectrum of ${ }^{1} \mathrm{O}_{2}$ phosphorescence upon photosensitized (a,d) and direct (b-d) excitation of oxygen in air saturated $\mathrm{CCl}_{4}$. a: Solution of TPP excited with $\mathrm{cw}$ LED $399 \mathrm{~nm}(4 \mathrm{~mW})$ in the absence of acetone (upper curve) and after addition of $50 \%$ acetone (lower curve); b: without TPP, upon oxygen excitation with a $765 \mathrm{~nm}$ diode laser $(900 \mathrm{~mW})$; c: without TPP, upon oxygen excitation with a $690 \mathrm{~nm}$ diode laser (1-3 W); d: phosphorescence spectra corresponding to the curves (a), (b) and (c) after subtraction of luminescence observed in the presence of acetone (from left to right). The maximal phosphorescence intensity was set to be 1 at each graph (see also $\left.{ }^{[32,35,36]}\right)$. 
of oxygen phosphorescence was detected using laser radiation at $\leq 300 \mathrm{~mW} / \mathrm{cm}^{2}$. The signal indicated in Figure 8 corresponds to the noise level. Nevertheless, our data suggest that the quantum efficiency of phosphorescence excitation at $628 \mathrm{~nm}$ was at least 15 times smaller than that under excitation at $765 \mathrm{~nm}$. This result correlates with recent data of Bagrov et al. ${ }^{[38]}$ who reported that phosphorescence signal arising under excitation at $630 \mathrm{~nm}$ is extremely weak. Perhaps, their registration system was more sensitive. However, it should be noted that the sensitivity of our device was limited by weak phosphorescence of the quartz cell in the IR region. For quantitative calculations, the phosphorescence of the quartz cell was subtracted from the total phosphorescence signal. It is not quite clear how this factor was taken into account in ref. ${ }^{[38]}$ No chemical trapping and no reliable phosphorescence signal were observed upon excitation at 740 and $810 \mathrm{~nm}$, where oxygen does not have any absorption bands.

On the other hand, as seen from Figure 5, in the presence of traps (tetracene or DPIBF), gold vapor laser (628 nm) caused rather rapid oxygenation of the traps with higher quantum efficiencies than under the $1273 \mathrm{~nm}$ light. Comparison of Figures 5 and 8 clearly supports an assumption that under red light (628 and $690 \mathrm{~nm}$ ) the traps themselves strongly contribute to generation of singlet oxygen. Mechanisms of these processes are presently unclear.

Thus, evidence was obtained that under ambient conditions, monomeric oxygen molecules work as photosensitizers of oxygenation reactions similarly to oxygen dimols appearing at high oxygen pressure. At normal pressure, dimols, as Figure 8 shows, virtually do not (or very weakly) sensitize ${ }^{1} \mathrm{O}_{2}$ formation, probably because their concentration is negligibly low. On the other hand, it follows from our experiments that no matter which vibrational or electronic level is initially populated in monomeric oxygen molecules chemical activity always belongs to the $\left[{ }^{1} \Delta_{\mathrm{g}}(v=0)\right]$ state.

\section{Absorption Coefficients of Dissolved Oxygen Molecules}

From kinetic analysis of the photooxygenation rates of chemical traps $\left(V_{\text {lasr }}, \mathrm{M} / \mathrm{s}\right)$ under direct oxygen excitation, absorbance (optical density) at the absorption maxima $\left(A_{\max }\right)$ of oxygen was calculated. For calculation and measurements several procedures were developed (see refs. ${ }^{[29-32]}$ for details). The best results were obtained from comparison of the rates of singlet oxygen production upon photosensitized and direct excitation of oxygen molecules using the following equation: ${ }^{[29-32]}$

$$
A_{\max }=\left(V_{\text {last }} / V_{p s t}\right)\left(I_{p s e x} / \alpha I_{\text {las }}\right) \Phi_{\Delta}\left(1-10^{-A p s}\right) / 2.3
$$

where $I_{\text {las }}$ and $I_{p s e x}$ are the incident photon flux in einstein $\times \mathrm{L}^{-1} \times \mathrm{S}^{-1}$ for light applied to excitation of oxygen and photosensitizer, respectively; $\Phi_{\Delta}$ is the yield of singlet oxygen generation by photosensitizing pigments (TPP and TPPS were employed in our experiments). The coefficient $\alpha$ reflects degree of overlapping of the action spectrum with the spectrum of laser radiation. For estimation of $\alpha$ we approximated the excitation spectra by Gaussian curves with the $20 \mathrm{~nm}$ half band width for the $1273 \mathrm{~nm}$ band, and with the $10 \mathrm{~nm}$ half band width for the $765 \mathrm{~nm}$ band using the "Origin" software. Apparently, if the wavelength of laser radiation exactly matches the absorption maximum of oxygen and the halfwidth of laser band is about $1 \mathrm{~nm}$, $\alpha=1$. Usually, the spectral maxima of diode lasers were shifted by $2-5 \mathrm{~nm}$ to shorter wavelengths from the oxygen maxima and the half band width varied from 10 to $4 \mathrm{~nm}$ in different experiments, therefore the calculated values of $\alpha$ changed within $0.2-0.9$ (see ${ }^{[27,28]}$ for details). Since for Eq. 1, only relative values of oxygenation rates are needed, these rates were measured in the $\Delta A / t$ units, where $\Delta A$ is a change of absorbance in the maxima of the absorption spectra of the traps and $t$ is time (minutes) of sample irradiation, $\Phi_{\Delta}$ for TPP was found to be $0.73 \pm 0.05 . .^{[29-32]}$ Knowing $A_{\max }$, one can calculate molar absorption coefficients of oxygen: $\varepsilon_{\max }=A_{\max } /\left[\mathrm{O}_{2}\right]$, where $\left[\mathrm{O}_{2}\right]$ is the molar concentration of oxygen in solutions, and the absorption cross section $\sigma_{\max }=2300 \varepsilon_{\max } / N_{a v}$, where $N_{a v}$ is the Avogadro number.

The first estimation of $A_{1273}$ and other absorption coefficients of dissolved oxygen was made using aerated carbon tetrachloride and tetracene as a chemical trap. ${ }^{[25]}$ The obtained absorption coefficient was about three orders higher than in gaseous oxygen at 1 bar pressure. This conclusion correlates with the results of estimation of the radiative lifetime $\left(\tau_{r}\right)$ of dissolved oxygen in $\mathrm{CCl}_{4}$ performed previously using detection of photosensitized singlet oxygen phosphorescence. The $\tau_{r}$ obtained from phosphorescence measurements was three orders smaller than that in rarified gas. ${ }^{[39,40]}$

Combination of Figures 4, 5 and 8 allows estimation of the absorption spectrum (relative intensities of the absorption maxima) of dissolved oxygen in $\mathrm{CCl}_{4}$ (Figure 9). As mentioned above, absorbance at 1273, 1070 and $765 \mathrm{~nm}$ was measured using chemical trapping method (Figures 5).

The peaks at shorter wavelengths could not be analyzed by the trapping method because of the photosensitizing effects of traps or their complexes with oxygen. However, relative amplitudes of the peaks at 630,690 and $765 \mathrm{~nm}$ were estimated from phosphorescence measurements in solutions having no traps (see Figure 8 and comments to it). In Figure 9, the peak heights at $765 \mathrm{~nm}$ indicated in Figures 5 and 8 were equalized and peaks caused by photosensitizing action of traps were removed. The resulting spectrum of dissolved oxygen in $\mathrm{CCl}_{4}$ is shown in Figure 9. Similar spectrum of oxygen was also obtained in $\mathrm{C}_{6} \mathrm{~F}_{6}$ (not shown).

It is seen from Figures 4-9, that the absorption spectrum of dissolved oxygen under ambient conditions differs greatly from the absorption spectra of oxygen at high pressure and in rarified gas. Compared to the spectrum at high pressure (Figure 2), there are no well pronounced dimol bands at 630 and $1070 \mathrm{~nm}$. The latter band exists, but the ratio $A_{1270} / A_{1070}$ is about 30 times smaller than that under high pressure. ${ }^{[29]}$ In rarefied gas, the bands at 1270 and $1070 \mathrm{~nm}$ are by three orders smaller than in the spectrum of dissolved $\mathrm{O}_{2}$.

In other solvents, in which the lifetime of singlet oxygen is much smaller than in $\mathrm{CCl}_{4}$, the spectral properties of oxygen were also estimated, although accurate investigation of the vibrational bands has not been done yet. ${ }^{[25-32]}$ The data of our group are summarized in Figure 10 and Table 1 . It is seen that $\varepsilon_{1273}$ clearly depends on solvents varying in the range $(1.5-5) \cdot 10^{-3} \mathrm{M}^{-1} \mathrm{~cm}^{-1}$. The minimal value 


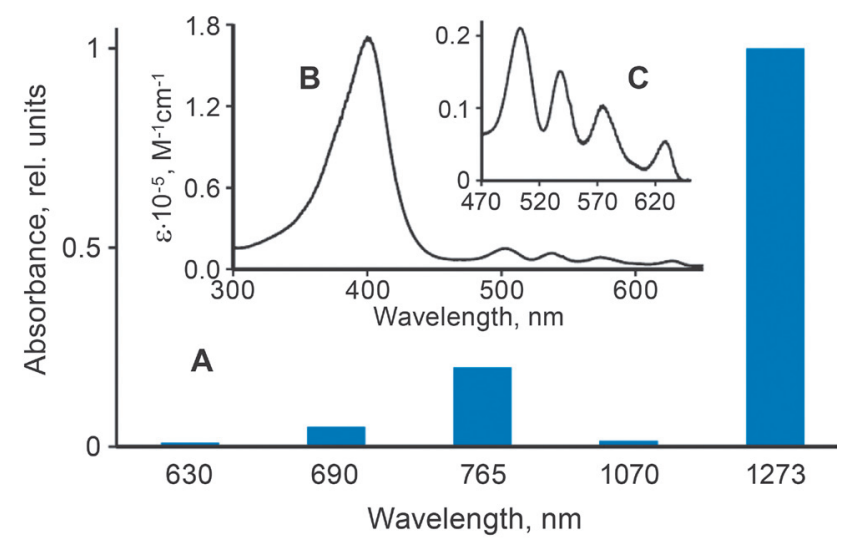

Figure 9. Absorption spectra of dissolved oxygen (A) in $\mathrm{CCl}_{4}$ and protoporphyrin IX in ethanol $(\mathrm{B}, \mathrm{C})$.

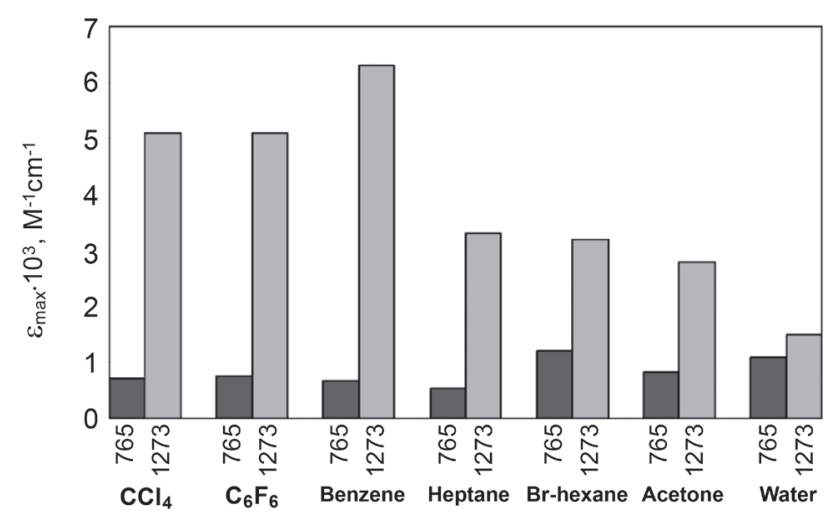

Figure 10. Absorption coefficients of oxygen in different solvents as reported in refs. ${ }^{[30-32]}$

was observed in water. In the solvents lacking heavy atoms the $\varepsilon_{765}$ varied within $(0.5-1.1) \cdot 10^{-3}$, having the maximal value in water. As a result, the ratios $\varepsilon_{1273} / \varepsilon_{765}$ changed from (4-10)/1 in organic solvents to $1.5 / 1$ in water.

Major results of our studies were confirmed by other researchers. $^{[12,33,34]}$ The absorption coefficients reported by different groups are rather similar. In acetone identical values of the absorption coefficients were obtained by all groups. In other solvents, the difference between the reported values does not exceed the factor of 2 . Ideally, all numbers should coincide. Therefore, attempts to improve the results will definitely be continued.

\section{Comparison with Porphyrins}

As follows from previous sections, the quantum efficiency $\left(Q_{o x}\right)$ of singlet oxygen generation by oxygen molecules can be described by the following equation:

$$
Q_{o x}=V_{g e n} / I_{e x}=2.3 A_{o x}=2.3 \varepsilon_{1273}\left[\mathrm{O}_{2}\right] l \text {, }
$$

where $V_{\text {gen }}$ is the rate of singlet oxygen production by oxygen, $I_{e x}$ is the intensity of exciting light (einstein $\times \mathrm{s}^{-1}$ ), $A_{o x}$ is absorbance of oxygen, $l$ is the optical path which was set to be equal to $1 \mathrm{~cm}$.

As mentioned above, the highest photosensitizing activity of oxygen was observed upon direct excitation of the main absorption bands at 1273 and $765 \mathrm{~nm}$. In water, the rate of singlet oxygen production by IR $(1273 \mathrm{~nm})$ light was smaller than that in organic solvents due to the lower solubility of oxygen and additional inactive absorption of light by water molecules (Figures 9, 10 and Tables 1,2). Far red light $(765 \mathrm{~nm})$ is probably more convenient for oxygen excitation in aqueous and biological systems, because oxygen absorption bands at 765 and $1273 \mathrm{~nm}$ are of almost the same height in these systems, whereas dark red light is not absorbed by water and does not cause water heating. ${ }^{[30-32]}$ Table 2 indicates the quantum efficiencies of the ${ }^{1} \mathrm{O}_{2}$ production upon direct oxygen excitation as calculated using Eq. 2 and the data of Table 1.

It is seen from Table 2 that in aerated water the quantum efficiency for oxygen excitation at $1273 \mathrm{~nm}$ is near $10^{-6}$ (1 cm optical path). In hydrophobic media $\left(\mathrm{CCl}_{4}\right.$ is used as a model) the quantum efficiency is 30 times higher $\left(3 \cdot 10^{-5}\right)$ because of higher solubility and higher molar absorption coefficient of oxygen in hydrophobic environment. In both cases, the quantum efficiency is restricted by low values

Table 1. Values of the oxygen absorption coefficients in several solvents calculated using Eq. 1, and the rates of oxygenation of the singlet oxygen traps under ambient conditions. ${ }^{[30-32]}$

\begin{tabular}{|c|c|c|c|c|c|}
\hline & $\begin{array}{c}A_{1273} \times 10^{5} \\
(1 \mathrm{~cm})\end{array}$ & $\begin{array}{c}A_{765} \times 10^{5} \\
(1 \mathrm{~cm})\end{array}$ & {$\left[\mathrm{O}_{2}\right], \mathrm{mM}^{[41]}$} & $\begin{array}{c}\varepsilon_{1273} \times 10^{3} \\
\mathrm{M}^{-1} \mathrm{~cm}^{-1}\end{array}$ & $\begin{array}{l}\varepsilon_{765} \times 10^{3} \\
\mathrm{M}^{-1} \mathrm{~cm}^{-1}\end{array}$ \\
\hline Gas phase, 1 bar & $\sim 0.1^{[4]}$ & $3.4^{[5]}$ & $\sim 40$ & 0.025 & 0.85 \\
\hline Carbon tetrachloride & 1.33 & 0.19 & 2.6 & 5.1 & 0.7 \\
\hline Hexafluorobenzene & 2.25 & 0.34 & 4.4 & 5.1 & 0.77 \\
\hline Benzene & 1.20 & 0.13 & 1.9 & 6.3 & 0.68 \\
\hline Toluene & 1.18 & 0.12 & 1.8 & 6.5 & 0.67 \\
\hline$n$-Heptane & 0.92 & 0.15 & 2.8 & 3.3 & 0.53 \\
\hline 1-Bromohexane & 0.96 & 0.36 & 3.0 & 3.2 & 1.2 \\
\hline Acetone & 0.66 & 0.20 & 2.4 & 2.8 & 0.83 \\
\hline Ethanol & 0.48 & 0.14 & 1.65 & 2.9 & 0.85 \\
\hline Water $+0.2 \mathrm{M} \mathrm{SDS}$ & 0.043 & 0.032 & 0.29 & 1.5 & 1.1 \\
\hline
\end{tabular}


Table 2. Quantum efficiencies $(Q)$ of singlet oxygen photosensitization by oxygen and protoporphyrin in aerated solutions calculated for $1 \mathrm{~cm}$ optical path.

\begin{tabular}{cccc}
\hline \multicolumn{4}{c}{ Photosensitization by $\mathrm{O}_{2}$} \\
\hline Solvents & $\lambda_{e x}, \mathrm{~nm}$ & $A_{o x} \times 10^{-5}$ & $Q_{o x} \times 10^{-5}$ \\
\hline $\mathrm{CCl}_{4}$ & 1273 & 1.33 & 3.1 \\
& 765 & 0.19 & 0.44 \\
& 630 & - & $\leq 0.03$ \\
\hline \multirow{2}{*}{ Water } & 1273 & 0.043 & 0.1 \\
& 765 & 0.032 & 0.74 \\
\hline
\end{tabular}

Photosensitization by protoporphyrin

\begin{tabular}{cccc}
\hline $\begin{array}{c}\text { Porphyrin } \\
\text { concentration }\end{array}$ & $\lambda_{\text {ex }}, \mathrm{nm}$ & $A_{\text {porf }} \times 10^{-5}$ & $Q_{\text {porf }} \times 10^{-5}$ \\
\hline $10 \mathrm{nM}$ & 630 & 3.5 & 6 \\
& 540 & 10 & 17 \\
& 400 & 120 & 210 \\
\hline $10 \mu \mathrm{M}$ & 630 & 3500 & 6000 \\
\hline
\end{tabular}

of the oxygen absorption coefficients. The activity of dimols under $630 \mathrm{~nm}$ light was shown to be at least 100 times smaller than that for monomols under excitation at $1273 \mathrm{~nm}$ (Figures 8 and 9, Table 2). Perhaps, this effect is due to negligible concentration of dimols in aerated systems under normal conditions.

According to literature data, normal tissues and blood serum contain 10-50 nM metal-free porphyrins, mostly protoporphyrin IX and coproporphyrin IX ([42-45] and refs. therein). It was proposed some time ago that the intrinsic porphyrins might be responsible for stimulation of metabolic processes in cells, such as acceleration of wound healing, pain relief, suppression of endotoxic shock and activation of immune cells under red light $\left({ }^{[21,42,43]}\right.$ and refs. therein). The absorption spectra of proto- and coproporphyrins are known to be rather similar. ${ }^{[46]}$ The absorption peaks of porphyrins overlap with the dimol absorption bands (compare Figures 2 and 9). The main absorption maximum of porphyrins is at $400 \mathrm{~nm}$. The amplitude of the next peak at $504 \mathrm{~nm}$ is 20 times less. Other peaks located at 539,576 and $630 \mathrm{~nm}$ are even smaller. Porphyrins have no absorption bands in the infrared region corresponding to the major absorption maxima of oxygen monomols. To estimate the quantum efficiencies for photosensitization by porphyrins $\left(Q_{\text {porr }}\right)$ the following equation was used:

$$
Q_{\text {porf }}=V_{\text {gen }} / I_{\text {ex }}=\Phi_{\Delta}\left(1-10^{-A \text { porf }}\right) \sim 2.3 \Phi_{\Delta} A_{\text {porf }},
$$

where $V_{\text {gen }}$ is the rate of singlet oxygen production by porphyrins, $I_{e x}$ is the intensity of exciting light (einstein $\times \mathbf{s}^{-1}$ ), $A_{\text {porf }}$ is absorbance of porphyrins, and $\Phi_{\Delta}$ is the quantum yield of singlet oxygen generation by porphyrin, which is known to be equal to $0.7-0.8{ }^{[47,48]}$ The results are summarized in Table 2.

Using molar extinction coefficients of protoporphyrin indicated in Figure 9, we arrive to the quantum efficiency for the protoporphyrin excitation at $630 \mathrm{~nm}(1 \mathrm{~cm}$ optical path) equal to $\approx 6 \cdot 10^{-5}$ in nanomolar porphyrin solutions. Hence under red light, the photosensitization efficiency of nanomolar solutions of porphyrins is greater at least by 2 orders of magnitude than that of oxygen.

Photosensitization efficiency of porphyrins strongly increases upon excitation at shorter wavelengths (green and violet). For instance, excitation by violet light $(400 \mathrm{~nm})$ is about 40 times more efficient that the excitation at $630 \mathrm{~nm}$ (Table 2). Based on this fact, one could expect that the porphyrin-sensitized stimulation of living cells by blue and green light might be much stronger than by red light. To our knowledge, proper investigation of this problem has not been done yet. Although, according to Karu's group the action of violet, green and red light is of comparable efficiency. ${ }^{[19,20]}$

The increase in the porphyrin concentration, causes proportional raise of the photodynamic efficiency of porphyrins (Table 2). As it was shown in our recent papers, upon excitation of the green absorption band $(\sim 510 \mathrm{~nm})$ of TPP in organic solvents (absorbance was $\sim 0.1$, concentration $\sim 5 \mu \mathrm{M})$ the quantum efficiencies were four orders greater than those upon laser excitation of dissolved oxygen at $1270 \mathrm{~nm} \cdot{ }^{[29,31]}$ Hence, photodynamic potential of micromolar concentrations of porphyrins is incomparably higher than that of dissolved oxygen (Table 2). Moreover, recent papers demonstrate that application of chlorins and bacteriochlorins expands the spectral range of photodynamically active light from blue to dark red region without losing the quantum efficiency of photosensitization. ${ }^{[49,50]}$

\section{Conclusions}

Thus, it has been shown that monomeric oxygen molecules photosensitize singlet oxygen formation in aerated organic solvents and water under normal conditions. The strongest effect was observed under excitation at 1273 and $765 \mathrm{~nm}$, much weaker activity was detected under excitation at 1070 and $690 \mathrm{~nm}$. With laser excitation at $630 \mathrm{~nm}$ corresponding to the absorption band of oxygen dimols, no sensitized generation of singlet oxygen was reliably observed, probably because of negligible concentration of dimols in aerated solutions. Kinetic analysis of the rates of singlet oxygen generation upon direct excitation of $\mathrm{O}_{2}$ molecules allowed estimation of absorbance and molar absorption coefficients corresponding to the absorption maxima of dissolved oxygen molecules. The quantum efficiencies of singlet oxygen production upon direct excitation of $\mathrm{O}_{2}$ have been estimated. The data suggest that photodynamic action of dissolved oxygen should be most efficient under IR light, whereas under red light $(630 \mathrm{~nm})$ oxygen molecules are virtually inactive.

On the contrary, photodynamic activity of porphyrins was observed under the action of red and visible light, no photosensitization was detected under IR irradiation. Table 2 indicates that at the $10 \mathrm{nM}$ porphyrin concentration corresponding to the normal content of metal-free porphyrins in cells and tissues the porphyrins produce under red light as much singlet oxygen as $\mathrm{O}_{2}$ molecules located in hydrophobic environment under irradiation by IR light. The quantum efficiencies of photosensitization by both oxygen and "nanomo- 
lar porphyrins" are very low. Therefore, it is unlikely that they cause appreciable destruction of living tissues under moderate laser power allowed for photodynamic and laser therapy $\left(\leq 200 \mathrm{~mW} \cdot \mathrm{cm}^{-2}\right)$. Indeed, it was shown that measurable rates of cell damage can be observed under direct excitation of dissolved oxygen by 1000 times greater laser power $-\geq 100 \mathrm{~W} \cdot \mathrm{cm}^{-2}$ at $1273 \mathrm{~nm} \cdot{ }^{[51]}$ Similar excitation power is probably needed for photodynamic damage by nanomolar porphyrins under red light. Perhaps, photobiological effects arising in these systems are due to light induced signaling processes. ${ }^{[52,53]}$

The increase in the porphyrin concentration causes proportional raise of the photodynamic efficiency of porphyrins. It is known that in wounds, tissues affected by porphyria and cancer tissues loaded by exogenic porphyrin photosensitizers for PDT, the concentration of porphyrins reaches 1000-10000 nM. Hence, photodynamic potential of micromole porphyrin concentrations is incomparably higher than that of dissolved oxygen (Table 2).

Nevertheless, many authors reported that IR (1270 nm) light of moderate power is biologically active and effective in treatment of certain tumors $\left({ }^{[17,54-57]}\right.$ and refs. therein). Molecular oxygen is often considered as a photoreceptor triggering biological processes via intermediate singlet oxygen formation. Biological action of red light $(630 \mathrm{~nm})$ is sometimes also ascribed to light absorption by oxygen molecules. Present paper demonstrates that it is much more likely that the action of red and visible light is due to photosensitizing activity of porphyrins or maybe other organic chromophores. The photosensitization by molecular oxygen is possible only under the action of IR light. As the quantum efficiency of this process is very low, one cannot exclude also the involvement of different mechanisms. For instance, it should be noted that bound and free molecules of water absorb IR light at 1070-1270 nm much stronger than oxygen. Also, IR light might influence signaling or immune processes in cells and tissues (see $\mathrm{s}^{[20,21,49,50,52,53]}$ and refs. therein). Thus, at the present stage of research, further mechanistic studies of these processes are needed.

Acknowledgements. This work was partially supported by the Russian Foundation for Basic Research (projects No 15-04-0550 and 19-04-00331). The firms "Surgical innovative technologies Ltd", "Polironik Ltd" (Moscow), "Alkom Medika Ltd" (St. Petersburg) and "Milon Lachta Ltd" (St. Petersburg) are gratefully acknowledged for diode lasers, LEDs and technical assistance.

\section{References}

1. Mulliken R.S. Phys. Rev. 1928, 32, 880-887.

2. Herzberg L., Herzberg G. Astrophys. J. 1947, 105, 353-359.

3. Galkin V.D. Opt. Spektrosk. 1979, 47, 266-270.

4. Badger R.M., Wright A.C., Whitlock R.F. J. Phys. Chem. $\mathbf{1 9 6 5}, 43,4345-4350$.

5. Greenblatt D.J., Orlando J.J., Burkholdera J.B., Ravishankara A.R. J. Geophys. Res. 1990, 95(D11), 18577-18582.

6. Dianov-Klokov V.I. Opt. Spektrosk. 1966, 20, 954-962.

7. Evans D.F. Chem. Commun. 1969, 367-368.

8. Matheson I.B.C., Lee J. Chem. Phys. Lett. 1971, 8, 173-176.

9. Long C., Kearns D.R. J. Chem. Phys. 1973, 59, 5729-5736.
10. Khan A.U. In: Singlet $O$, Vol. 1 (Frimer A.A., Ed.) Florida: CRC Press, Boca Raton, 1985, p. 31-79.

11. Gurinovich G.P. J. Appl. Spectrosc. 1991, 54, 403-411.

12. Bregnhøj M., Krǣgpøth M.V., Serensen R.J., Westberg M., Ogilby P.R. J. Phys. Chem. A 2016, 120, 8285-8296.

13. Matheson I.B.C., Lee J. Chem. Phys. Lett. 1970, 77, 475-476.

14. Matheson I.B.C., Lee J. Photochem. Photobiol. 1979, 29, 879-881.

15. Ambartzumian R.V. Proc. SPIE 1986, 701, 341-343 (http: // spie.org/publications/proceedings/volume/0701).

16. Ambartzumian R.V., Eliseev P.G., Eremeev B.V., et al. Kratkiye Soobshch. po Fizike, Fizich. Institut im. Lebedeva RAN [Short Commun. in Physics, P.N. Lebedev Physics Institute RAS] 1987, 35-37 (in Russ.).

17. Zakharov S.D., Ivanov A.V. Quantum Electronics 1999, 29, 1031-1053.

18. Gamaleya N.F. In: Laser Applications in Medicine and Biology (Wolbarsht M.L., Ed.) New York: Plenum Press, 1977. p. $1-172$.

19. Karu T.I., Kalendo G.S., Letokhov V.S., Lobko V.S. Nuovo Cimento 1982, $1 D(6), 828-840$.

20. Karu T.I. Photochem. Photobiol. 2008, 84, 1091-1099.

21. Vladimirov Yu.A., Osipov A.N., Klebanov G.I. Biochemistry 2004, 69, 81-90.

22. Blázquez-Castro A. Redox Biology 2017, 13, 39-59.

23. Krasnovsky A.A., Jr., Drozdova N.N., Ivanov A.V., Ambartzumian R.V. Biochemistry 2003, 68, 963-966.

24. Krasnovsky A.A., Jr., Ambartzumian R.V. Chem. Phys. Lett. 2004, 400, 531-535.

25. Krasnovsky A.A., Jr., Drozdova N.N., Roumbal Ya.V., Ivanov A.V., Ambartzumian R.V. Chin. Opt. Lett. 2005, 3(S1), S1-S4.

26. Krasnovsky A.A., Jr., Roumbal Ya.V., Ivanov A.V., Ambartzumian R.V. Chem. Phys. Lett. 2006, 430, 260-264.

27. Krasnovsky A.A., Jr., Kryukov I.V., Sharkov A.V. Proc. SPIE 2007, 6535, 65351Q1-5.

28. Krasnovsky A.A., Jr., Roumbal Ya.V., Strizhakov A.A. Chem. Phys. Lett. 2008, 458, 195-199.

29. Krasnovsky A.A., Jr., Kozlov A.S., Roumbal Ya.V. Photochem. Photobiol. Sci. 2012, 11, 988-997.

30. Krasnovsky A.A., Jr., Kozlov A.S. Biofizika 2014, 59, 199-205.

31. Krasnovsky A.A., Jr., Kozlov A.S. J. Photochem. Photobiol. A: Chemistry 2016, 329, 167-174.

32. Krasnovsky A.A., Jr., Kozlov A.S. J. Biomed. Photon. Eng. 2017, 3, 010302.

33. Anquez F., Courtade E., Sivery A., Randoux S. Opt. Express 2010, 18, 22928-22936.

34. Sivery A., Barras A., Boukherroub R., Pierlot C., Aubry J.M., Anquez F., Courtade E. J. Phys. Chem. C 2014, 118, 2885-2893.

35. Benditkis A.S., Kozlov A.S., Goncharov S.E., Krasnovsky A.A., Jr. Proc. Int. Conf. on Laser Optics (ICLO 2018), IEEE Xplor Digital Library, 2018. p. 598.

36. Krasnovsky A.A., Benditkis A.S., Kozlov A.S. Biochemistry 2019, 84, 153-163.

37. Afshari E., Schmidt R. Chem. Phys. Lett. 1991, 184, 128-132.

38. Bagrov I.V., Kiselev V.M., Kislyakov I.M., Sosnov E.N. Opt. Spectrosc. 2014, 116, 567-574.

39. Krasnovsky A.A., Jr. Chem. Phys. Lett. 1981, 81, 443-445.

40. Schweitzer C., Schmidt R. Chem. Rev. 2003, 103, 1685-1757.

41. Murov S.L., Charmichael I., Hug G.L. Handbook of Photochemistry, Marcel Dekker Inc. New York: Basel, Hong Kong, 1993. p. 290.

42. Krivosheev A.B., Konratieva M.A., Tuguleva T.A., Morozov D.V. Russian Journal of Skin and Venereal Diseases 2015, 18(3), 30-35 (in Russ.).

43. Machneva T.V., Bulgakova N.N., Vladimirov Yu.A., Osipov A.N. Biophysics 2011, 55, 532-538. 
44. Machneva T.V., Buravlev E.A., Bulgakova N.N., Vladimirov Yu.A., Osipov A.N. Biophysics 2011, 56, 687-694.

45. Grubina L.A., Zenkevitch E.I. In: Uspekhi Khimii Porfirinov [Advances in Porphyrin Chemistry], Vol. 3 (Golubchikov O.A., Ed.) St. Petersburg: Publ. House of St. Petersburg University, 2001. p. 160-178 (in Russ.).

46. Gurinovich G.P., Sevchenko A.N., Solovyov K.N. Spectroscopy of Porphyrins and Related Compounds. Minsk: Nauka i Tekhnika, 1967 (in Russ.) [Гуринович Г.П, Севченко А.Н., Соловьев К.Н. Спектроскопия порфиринов и родственных соединений. Минск: Наука и техника, 1967].

47. Venediktov E.A., Krasnovsky A.A., Jr. Zh. Prikl. Spektr. [J. Applied Spectroscopy] 1982, 36(1), 152-154 (in Russ.).

48. Dzhagarov B.M., Gurinovich G.P., Novichenkov V.E., Salokhiddinov K.I., Shulga A.M., Ganza V.A. Russ. Chem. Phys. (Khimicheskaya Fizika) 1987, 6, 1069-1078.

49. Krasnovsky A.A., Jr., Vychegzanina I.V., Drozdova N.N., Krasnovsky A.A. Dokl. AN SSSR (Biophysics) 1985, 283, 474- 477.
50. Mironov A.F., Grin M.A., Tsiprovskii A.G., Segenevich A.V., Dzardanov D.V., Golovin K.V., Tsygankov A.A., Shim Ya.K. Russ. J. Bioorg. Chem. 2003, 29, 190-197.

51. Anquez F., Yazidi-Belkoura I.E., Randoux S., Suret P., Courtade E. Photochem. Photobiol. 2012, 88, 167-174.

52. Klotz L.O., Kronke K-D., Sies H. Photochem. Photobiol. Sci. 2003, 2(2), 88-94.

53. Antony R.J., Warczak K.L., Donohue T.J. Proc. Natl. Acad. Sci. USA 2005, 102, 6502-6507.

54. Yusupov A.S., Goncharov S.E., Zalevskii I.D., Paramonov V.M., Kurkov A.S. Laser Physics 2010, 20, 357-359.

55. Ambartzumian R.V. Laser Medicine 2016, 20(2), 62-63 (in Russ.).

56. Alekseev Yu.V., Barkhina T.G., Ivanov A.V., Davidov E.V., Kovalev M.I., Kovaleva A.M. Laser Medicine 2018, 22(2), 29-35 (in Russ.).

57. Saenko Y.V., Glushenko E.S., Zolotovskii I.O., Sholokhov E., Kurkov A.S. Lasers Med. Sci. 2016, 31, 405-413. 